Research

\title{
Mometasone furoate effect on interleukin-6 of adenoid surface and serum in adenoid hypertrophy patients
}

\author{
Zainul Mujahid, Rus Suheryanto, Iriana Maharani \\ Department of Otorhinolaryngology Head and Neck Surgery \\ Faculty of Medicine, Brawijaya University / Dr. Saiful Anwar General Hospital, \\ Malang
}

\begin{abstract}
Background: Adenoid hypertrophy is one of the most common problems in children resulting in obstruction of the posterior nasal cavity. Interleukin-6 (IL-6) is a pleiotropic cytokine that plays a role in acute and chronic infections, hematopoesis, T cells and B cells formation. Purpose: To determine the effect of intranasal mometasone furoate administration on IL-6 level of adenoid surface and serum and the adenoid size in patients with adenoid hypertrophy. Method: A one group pre- and post-test design involving 17 patients aged 5 to 12 years. The subjects underwent nasoendoscopic examination to determine the adenoid size, also measurement of IL- 6 level of adenoid surface and serum before and after 6 weeks treatment with intranasal mometasone furoate. Results: There were a significant decrease of the adenoid surface IL-6 level, serum IL-6 level, and adenoid size with $p$ value $<0.05$. There was a significant positive correlation between the levels of adenoid surface IL- 6 and serum IL- $6(r=0.517 ; p=0.033)$. A significant positive correlation was obtained between the decrease of adenoid surface and serum IL-6 levels with the decrease of adenoid size $(p<0.05)$. Conclusion: The use of intranasal mometasone furoate could decrease the IL-6 levels of adenoid surface and serum, and the adenoid size in patients with adenoid hypertrophy.
\end{abstract}

Keywords: adenoid hypertrophy, interleukin-6, intranasal mometasone furoate

\begin{abstract}
ABSTRAK
Latar belakang: Hipertrofi adenoid merupakan salah satu masalah tersering pada anak-anak yang mengakibatkan obstruksi pada rongga hidung posterior. Interleukin-6 merupakan sitokin pleiotropik yang berperan pada infeksi akut maupun kronis, hematopoesis, pembentukan sel T dan sel B. Tujuan: Mengetahui pengaruh pemberian mometason furoat intranasal terhadap kadar IL-6 permukaan adenoid dan serum, serta ukuran adenoid pada penderita hipertrofi adenoid. Metode: Suatu one group pre- and post-test design melibatkan 17 subjek berusia 5 sampai 12 tahun. Subjek menjalani pemeriksaan nasoendoskopi, pengukuran kadar IL-6 serum, dan IL-6 permukaan adenoid sebelum dan setelah pemakaian mometason furoat intranasal selama 6 minggu. Hasil: Didapatkan penurunan kadar IL-6 permukaan adenoid, IL-6 serum, dan penurunan ukuran adenoid yang bermakna dengan nilai $p<0,05$. Didapatkan korelasi positif yang signifikan antara kadar IL-6 permukaan adenoid dengan IL-6 serum ( $r=0,517 ; p=0,033)$. Didapatkan korelasi positifyang signifikan antara penurunan kadar IL-6 permukaan adenoid dan IL-6 serum dengan pengecilan ukuran adenoid $(p<0,05)$. Kesimpulan: Penggunaan mometason furoat intranasal dapat menurunkan kadar IL-6 permukaan adenoid dan IL-6 serum, serta ukuran adenoid pada penderita hipertrofi adenoid.
\end{abstract}

Kata kunci: hipertrofi adenoid, interleukin-6, mometason furoat intranasal

Correspondence address: Zainul Mujahid. Department of Otorhinolaryngology Head and Neck Surgery, Faculty of Medicine, Brawijaya University / Dr. Saiful Anwar General Hospital, Malang. Email: zainulmujahid83@gmail.com. 


\section{INTRODUCTION}

The adenoids are a collection of lymphatic tissue located in the most superior-posterior aspect of the nasopharynx. Being a lymphoid tissue, the adenoids play a role in immunity housing large numbers of immune-competent cells such as B cells, T cells, lymphocytes, and macrophages. As a result, the adenoids are highly prone to inflammation when an immune response is elicited against foreign antigens. Even in healthy children, a physiologic amount of adenoid enlargement is a part of normal craniofacial growth and development. The adenoid lymphoid tissue naturally increases to its largest size sometime between age 5-10 years, then continually decreases in size until adulthood. ${ }^{1}$

Adenoid hypertrophy is one of the most common health problems in children causing obstruction in the posterior nasal cavity. Health problems that arise depend on the degree of obstruction that occurs by adenoid hypertrophy. Children with adenoid hypertrophy may experience Eustachian tube dysfunction or otitis media, rhinosinusitis, obstructive sleep apnea (OSA), maxillofacial growth abnormalities, speech disorders, and impaired quality of life. OSA has been estimated to affect about $2-3.5 \%$ of children. The peak occurs in children from 2 to 8 years of age, with the presence of enlarged adenoid and / or tonsils. ${ }^{1,2}$

The IL-6 is a pleiotropic agent and is currently known to have a role as a hormone that affects vascular disease, lipid metabolism, insulin resistance, mitochondrial activity, the neuroendocrine system and neuropsychological behavior. Interleukin-6 is a pro-inflammatory cytokine that is able to induce the population expansion and activation of $\mathrm{T}$ cells, the differentiation of $\mathrm{B}$ cells, and regulation of the acute-phase response. ${ }^{3}$

There is an increase in IL-6 levels both in the serum and in the adenoids and palatine tonsils in chronic adenotonsillitis. A few studies had examined the expression of cytokines on the surface of adenoids in the process of host immunity. Ivarsson et al. ${ }^{4}$ reported that $\mathrm{T}$ cells in the adenoid surface secretion (AdSS) have a role in cytokine production and down regulation, especially the Th1 type. The analyzed samples had been able to produce cytokines such as interferon (IFN)- $\mathrm{\gamma}$, IL-2, IL-5, IL-10, especially IFN-y. Wang et al..$^{5}$ observed the IL-6 expression of adenoid surfaces in patients with adenoid hypertrophy.

Based on the Pan-American clinical practice guideline for medical management of acute tonsillitis and adenoids hypertrophy, intranasal corticosteroids are the first-line medical treatment to achieve decrease of size and symptoms improvement. ${ }^{6}$ The use of intranasal corticosteroids in adenoid hypertrophy was first reported by Demain and Goetz (1995) showing a decrease in adenoid size after eight weeks. ${ }^{7}$ Currently there are various intranasal topical corticosteroid such as triamcinolone acetonide, budesonide, fluticasone propionate, fluticasone furoate, and mometasone furoate. ${ }^{8}$

Mometasone furoate is one of the latest generation of intranasal corticosteroids, which is a potent 17-heterocyclic corticosteroid. In vitro comparison showed that mometasone furoate has a high affinity for binding to glucocorticoid receptors (GR) and more potent stimulators for gene expression mediated by GR than other topical corticosteroids. Because of its low systemic bioavailability, mometasone furoate has very minimal systemic effect and can even be ignored at the recommended dosage so that it does not cause clinically significant side effects. ${ }^{9}$

This study aimed to find out the effect of intranasal mometasone furoate administration on IL-6 level of adenoid surface and serum and the adenoid size in patients with adenoid hypertrophy. 


\section{METHOD}

This was a prospective study with a one group pre- and post-test design. Data collection was carried out before and after treatment without being compared with a control group. The subjects in this study were all adenoid hypertrophy patients who came to the Ear Nose and Throat (ENT) outpatient clinic of Dr. Saiful Anwar General Hospital Malang, from October 2019 to February 2020. A consecutive sampling was used for sample collection. Inclusion criteria were children aged 5-14 years with symptoms and signs of adenoid hypertrophy, supported by lateral cervical X-ray soft tissue settings that met the Cohen and Konak criteria in which $\mathrm{AC} / \mathrm{SfP}$ ratio was less than 1.1. Additionally, patients should have negative skin prick tests, and did not have acute inflammation/ infection with leukocyte value within the normal range of 5,000-11,000/ $\mu \mathrm{L}$, erythrocyte sedimentation rate less than $30 \mathrm{~mm} /$ hour and C-reactive protein less than $0.8 \mathrm{mg} / \mathrm{dL}$. The exclusion criteria were children who suffer from congenital deformities of the facial area, oral cavity, and nose, nasal obstruction due to deviated nasal septum, nasal polyposis, or inferior turbinate hypertrophy. Patients who had received systemic or intranasal corticosteroid and antibiotic in the last one month were also excluded.

Nasoendoscopic examinations were performed to the patients to determine the size of the adenoid using $0^{\circ}$ rigid nasal endoscope with diameter of $2.7 \mathrm{~mm}$ or 4 $\mathrm{mm}$. The adenoid size measured as the ratio of the diameter of the adenoids to the choanal diameter in superoinferior and laterolateral lines. The ratio expressed as a percentage.

The adenoid surface IL-6 samples were taken from nasopharyngeal washing, using a disposable syringe containing $2 \mathrm{ml}$ of sterile normal saline connected with gastric tube $8 \mathrm{Fr}$. The patient was placed in supine position with the head extended, then the tube inserted gently through the nasal cavity into the nasopharynx. The normal saline was sprayed and immediately aspirated again. Fluid samples were placed in specimen tubes.

Serum IL-6 was taken from peripheral venous blood samples. The serum and adenoid surfaces IL-6 samples were measured with enzyme-linked immunosorbent assay (ELISA) technique by LEGEND MAX ${ }^{\mathrm{TM}}$ Human IL-6 ELISA Kit. The assays were conducted according to the manufacturer's guidelines at the Biomedik Laboratory, Faculty of Medicine, Brawijaya University. IL-6 levels were expressed in units of $\mathrm{pg} / \mathrm{mL}$.

The subjects were given mometasone furoate intranasal (Nasonex $\left.{ }^{\circledR}\right)$ at the dose of $100 \mu \mathrm{g}$ /day (one spray per nostril) for patients aged 5-11 years, and $200 \mu \mathrm{g} /$ day (two sprays each nostril) for aged 12-14 years, used for 6 weeks period. Patients were asked to come back every 2 weeks to evaluate any complaints, side effects, and compliance with drug use by weighing the bottle of mometasone furoate. At the sixth week, nasoendoscopic examination, and adenoid surface and serum IL-6 samples collection procedure were repeated.

The data was analyzed using the Statistical Package for the Social Sciences (SPSS) version 25. Data distribution was assessed using Shapiro Wilks normality test. The comparison of adenoid surface IL-6, serum IL-6 level, and adenoid size before and after the treatment were analyzed using paired t-test if normally distributed or Wilcoxon test if not normally distributed. The correlation between changes in IL-6 levels of adenoid surfaces, serum, and adenoid size were analyzed using Pearson's correlation test if normally distributed or Spearman's correlation test if not normally distributed. Ap value $<0.05$ was considered to be statistically significant.

The protocol was explained to parents before they signed the informed consent for their child to participate in the study. This study had been approved by the ethical committee of Dr. Saiful Anwar General Hospital (No. 400/164/K.3/302/2019). 


\section{RESULTS}

The study was conducted with a total sample of 18 subjects who met the research criteria. One participant could not complete the 6 weeks study. A total of 17 patients were included in the analysis. All patients and parents were able to cooperate in each examination procedure, and no side effects or complications were reported.

Table 1. General and clinical characteristics of research subjects

\begin{tabular}{lcc}
\hline \multicolumn{1}{c}{ Characteristics } & n & $\%$ \\
\hline Gender & 13 & 76.5 \\
Male & 4 & 23.5 \\
Female & & 82.4 \\
Age group & 14 & 17.6 \\
5-11 years & 3 & \\
12-14 years & $8.35 \pm 3.2$ & 88.2 \\
Mean age (years) & & 82.4 \\
Symptoms & 15 & 47.1 \\
Snoring & 14 & 58.8 \\
Nasal blockage & 8 & 58.8 \\
Sleep apnea & 10 & 76.5 \\
Hyponasal speech & 10 & 11.8 \\
Mouth breathing & 13 & 5.9 \\
Rhinorrhea & 2 & 5.9 \\
Hearing loss & 1 & 47.1 \\
Adenoid facies & & 5.9 \\
Body Mass Index (BMI) & 1 & 41.2 \\
Underweight & 8 & \\
Normal & 1 & \\
Overweight & $19.42 \pm 5.17$ & \\
Obesity & & \\
\hline
\end{tabular}

The mean size of adenoids were decreased from $79.76 \pm 13.18 \%$ to $67.59 \pm 15.19 \%$ after 6 weeks treatment of intranasal mometasone furoate. But there were two patients (patient no. 13 and 17) did not experience a decrease in the adenoid size (Figure 1). There was a statistically significant decrease in adenoid size after treatment $(\mathrm{p}<0.05)$ on paired-t test analysis. Nasoendoscopic view of adenoids before and after treatment in one of the patients is shown in Figure 2.

The mean level of adenoid surface IL-6 at the start of the study was $78.09 \pm 12.28 \mathrm{pg} /$ $\mathrm{mL}$, whereas after treatment was decreased to $62.46 \pm 14.51 \mathrm{pg} / \mathrm{mL}$ (Figure 4). There was a statistically significant decrease in the level of IL- 6 adenoid surface $(p<0.05)$ on paired- $t$ test analysis.
The mean level of serum IL- 6 at the beginning of the study was $71.05 \pm 12.66$ $\mathrm{pg} / \mathrm{mL}$, whereas after treatment was 54.46 $\pm 14.19 \mathrm{pg} / \mathrm{mL}$ (Figure 3). There was a statistically significant decrease in serum IL-6 levels $(p<0.05)$ after treatment on paired- $t$ test analysis.

The correlation between the serum IL- 6 levels and IL-6 adenoid surfaces before treatment showed a significant positive correlation $(p=0.033)$ with a moderate correlation level $(\mathrm{r}=0.517)$ on Pearson's correlation test. Moreover, a significant positive correlation was obtained $(\mathrm{p}=0.002)$ with a strong correlation level $(\mathrm{r}=0.706)$ after the treatment. These indicate that as adenoid surface IL-6 level increased, serum IL-6 level also increased. 


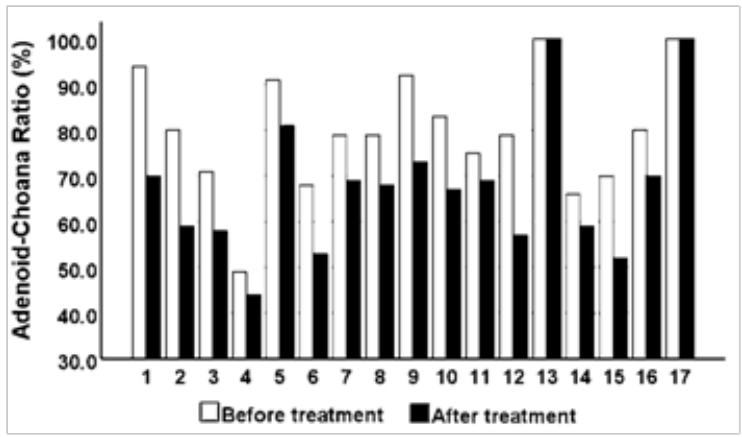

Figure 1. The size of the adenoids according to the adenoid-choana ratio before and after treatment

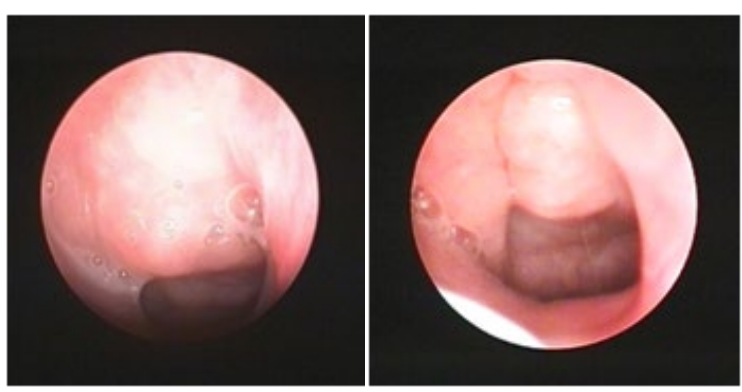

Figure 2. The adenoid nasoendoscopic view before (A) and after (B) treatment

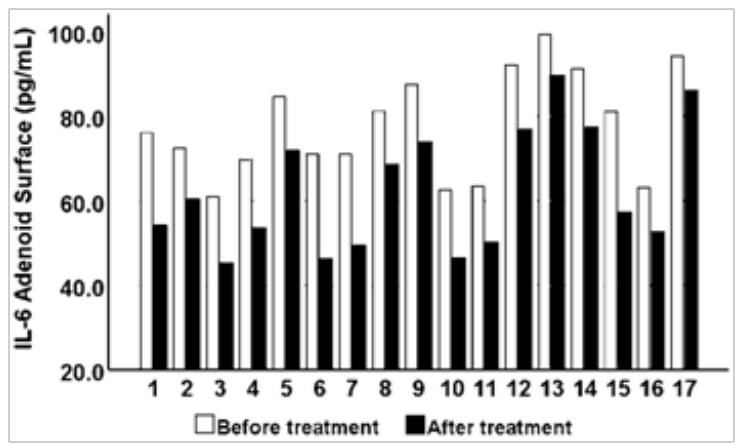

Figure 3. Adenoid surfaces IL-6 levels before and after treatment

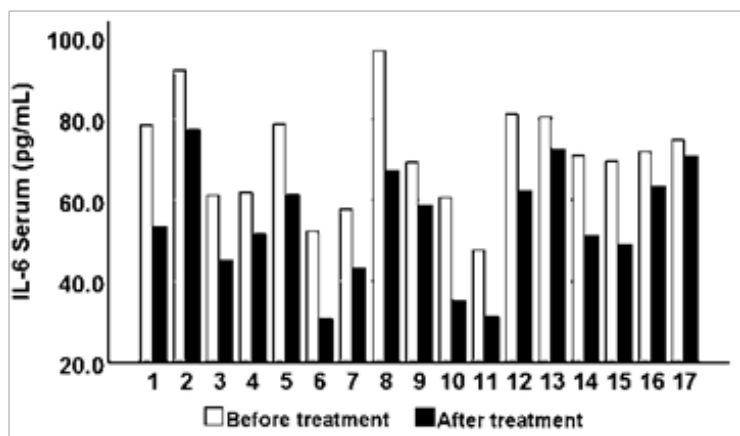

Figure 4. Serum IL-6 levels before and after treatment
Correlation analysis between the decrease in adenoid size and the decrease in serum IL-6 levels showed a significant positive correlation $(\mathrm{p}=0.024)$ at moderate correlation levels ( $\mathrm{r}=0.543$ ) with the Pearson's correlation test. This shows that the greater the reduction in adenoid size, the greater the decrease in serum IL-6 levels.

Correlation analysis between the decrease in adenoid size and the decrease in adenoid surface IL-6 levels showed a significant positive correlation $(\mathrm{p}=0.020)$ at moderate correlation level $(\mathrm{r}=0.558)$ with the Pearson's correlation test. This shows that the greater the reduction in adenoid size, the greater the decrease in adenoid surface IL-6 levels.

Correlation analysis between decreased serum IL-6 levels and decreased adenoid surface IL-6 levels showed a significant positive correlation $(\mathrm{p}=0.016)$ at moderate correlation level $(\mathrm{r}=0.573)$ with the Pearson's correlation test. This shows that the greater the decrease in serum IL-6 levels, the greater the decrease in adenoid surface IL-6 levels.

\section{DISCUSSION}

In this study it was found that most patients experienced symptoms of snoring $(88.2 \%)$, followed by nasal congestion $(82.4 \%)$, rhinorrhea $(76.5 \%)$, waking up at night due to sleep apnea (47.1\%), mouth breathing $(58.8 \%)$, hyponasal speech $(58.8 \%)$, and hearing loss (11.8\%). The symptoms that found in this study are consistent with the general clinical manifestations in patients with adenoid hypertrophy.

In adenoid hypertrophy there is a difficulty in breathing through the nose so that occurs mouth breathing, hyponasal speech, snoring, and sometimes obstructive sleep apnea (OSA). In recent times, OSA in the pediatric population is of particular concern. The main cause of sleep apnea is related to impaired upper airway patency 
specifically due to adenoid and / or tonsillar hypertrophy. Chronic hypoxia in children can cause changes in behavior, excitability, aggressive behavior, impaired concentration, decreased educational ability, and nocturnal enuresis. ${ }^{1,10}$

In this study, a total of $76.5 \%$ of the patients have rhinorrhea. Nasal obstruction resulting from adenoid hypertrophy could cause retention of secretions (mucus) in the nasal cavity and occurred as chronic rhinorrhea. This condition might progress to chronic rhinosinusitis. ${ }^{10}$ However, there was no apparent abnormality in the nasal cavity from nasoendoscopic examination that suggested the patients of this study were having rhinosinusitis.

There were 2 patients with hearing impairment in this study, and the adenoid size of these patients were $79 \%$ and $94 \%$ by nasoendoscopic examination. The enlarged adenoids that obstruct the Eustachian tube orificium may disturb the ventilation function of the middle ear, resulting in conductive hearing loss. ${ }^{10}$

In this study there was one patient with adenoid facies (patient no. 17). Prolonged mouth breathing has an influence on the development of the facial skeleton, resulting in a so-called adenoid facies, with manifestations of small and revoked jaw, narrow and higharched palatal, dental malocclusion, and oblong face. ${ }^{1,10}$

Based on the BMI criteria, our study found $5.9 \%$ with underweight, $47.1 \%$ with normo-weight, $5.9 \%$ with overweight, and $41.2 \%$ with obesity. Adenoid and tonsillar hypertrophy are major contributors to the etiology of OSA in normal-weight preschool children. Adipose tissue deposited around the pharynx and neck, along with hypertrophic adenoids and tonsils, largely contribute to obstructive sleep syndrome in obese children. ${ }^{11}$
In this study, the adenoid size based on the adenoid/choana ratio was statistically decreased significantly after the use of intranasal mometasone furoate. This was similar with the study conducted by Al-Harbi et al. ${ }^{12}$, Solmaz et al. ${ }^{13}$, and Yilmaz et al. ${ }^{14}$ which evaluated the adenoid size based on nasal endoscopy examination.

There is a histomorphological change in the epithelial crypts, extrafollicular area, and lymphoid follicle region of hypertrophic adenoid tissue. These changes could be seen as hyperplasia and hypertrophy due to chronic inflammatory processes. Patients with adenoid hypertrophy have a higher number of antigen presenting cells (APC) than normal adenoid tissue in pseudostratified columnar epithelium. While in the extrafollicular area there is an increase in interfollicular fibrosis tissue. ${ }^{15}$

The mechanism of intranasal corticosteroids in reducing the size of adenoids in patients with adenoid hypertrophy remains obscure. It is suspected that intranasal corticosteroid caused direct lympholytic effects, reduced adenoid and nasopharyngeal inflammation from its anti-inflammatory effects and decreased the role of adenoids as reservoirs of infection. ${ }^{14,16}$

The anti-inflammatory effect of corticosteroids is mediated by glucocorticoid receptors (GR). GR $\alpha$ are expressed in almost all tissues and cells, and their concentration is significantly higher than GR $\beta$. Therefore, the biological effects of glucocorticoids are mainly through binding to GR $\alpha$, thus allowing the ligand receptor complex to bind specifically to the target gene region. GR $\beta$ do not bind to glucocorticoids and mainly interact with DNA. GR $\beta$ is found in the nucleus and acts as a natural dominant inhibitor for GR $\alpha .^{17}$ In the tonsil and adenoid lymphoid tissues the expression of GR $\alpha$ and GR $\beta$ are mainly identified in the epithelial layer and extrafollicular areas of the parenchym. In contrast, the lymphoid follicular region does not express GR. ${ }^{18}$ 
Apoptosis regulates the life span of inflammatory cells. An increased or decreased in apoptosis determines the course of the inflammatory process. The decrease in apoptosis represents chronic inflammation and increased severity of a disease. ${ }^{19}$ Corticosteroids can affect the immune system in cell apoptosis. For dendritic cells as APC for example, corticosteroids suppress the maturation of dendritic cells, thus turning them into tolerogenic dendritic cells that have weak $\mathrm{T}$ cell stimulation activity. Dendritic cell migration and apoptosis are also controlled by corticosteroids. ${ }^{20}$

There were two patients $(11.76 \%)$ who had no changes in the adenoid size, however there was improvement in the symptoms. Similar results were reported by Kulekci et al. ${ }^{16}$ that $25 \%$ of patients studied have no experience adenoid reduction from nasoendoscopy evaluation after using mometasone furoate for 8 weeks, but symptoms or complaints were decreased. Both patients in our study were male and aged over 12 years old. Inoshita et al. ${ }^{21}$ reported that in the adolescent group ( $8-15$ years) the male airway is narrower and the adenoid/nasopharyngeal ratio is greater than that of female adolescents. It is also suspected because of the role of estrogen in the adenoid-tonsil tissue regression in puberty of female patients, whereas not so in male. The IL- 6 of adenoid surface and serum of the patient were also higher than other patients. The IL-6 is a proinflammatory cytokine and has an antiapoptotic role. ${ }^{22}$

The concentration of GR $\alpha$ and its affinity for glucocorticoids is positively correlated with glucocorticoid efficacy. The decreased in the corticosteroid sensitivity is associated with the increased GR $\beta$ expression or decreased GR $\alpha / G R \beta$ ratio. This results in the resistance against suppression of the number of inflammatory cells in the tissue by topical corticosteroids. The GR $\beta$ holds an antagonist role that can inhibit signaling pathways of active GR $\alpha$ and can cause a secondary resistance to glucocorticoids. ${ }^{23}$
The correlation between serum IL-6 levels and adenoid surfaces IL-6 showed a significant positive correlation. Moreover, the serum IL-6 levels in all samples were higher than normal levels, whereas serum IL-6 levels in physiological conditions were relatively low at $1-5 \mathrm{pg} / \mathrm{mL}$. Interleukin-6 is a pleiotropic cytokine. In addition to its role in the acute phase response, IL-6 has a variety of roles in promoting chronic inflammation, autoimmunity, endothelial cell dysfunction, and fibrogenesis. ${ }^{3}$

Proinflammatory cytokines such as tumor necrosis factor (TNF)- $\alpha$, IL-6, and IL- $1 \alpha$ are elevated in the lymphoid tissues of children with OSA, possibly secondary to repeated infections or in response to repeated snoring. ${ }^{24}$ The expression of proinflammatory cytokines in lymphoid tissue plays an important role in the growth and differentiation of $\mathrm{B}$ cells. Production and differentiation of $\mathrm{T}$ cells during an immune reaction have important regulatory effects on the course of immune activation. The presence of high concentrations of IL-6 in tissues is an expression of local hyperproduction, due to monocyte-macrophage activation, which is caused by an inflammatory response. Interleukin-6 is mainly released by APCs, such as macrophages and interdigitating cells. $^{25}$

Mutlu et al. ${ }^{26}$ reported that serum levels of IL-6, C-reactive protein (CRP) and TNF- $\alpha$ were increased in children with OSA especially those who had adenotonsillar hypertrophy planned for adenotonsillectomy. The levels of IL-6, CRP, and TNF- $\alpha$ were significantly lower at 6 months postoperatively when compared with baseline values.

Changes in the serum IL-6 that are influenced by local responses to adenoids can be explained through the existence of a series of induction mechanisms in chronic inflammation in adenoids. Chronic inflammation is characterized by the recruitment of monocytes to the area of inflammation played by IL-6. 
The IL- 6 and sIL-6R $\alpha$ complexes that bind to gp130 through the trans-signaling mechanism can activate endothelial cells to produce IL-8, monocyte chemoattractant protein (MCP)-1, inducing the expression of adhesion molecules, and IL-6 secretion by endothel. This chain of process is what can increase serum IL-6 levels. Prolonged IL-6 increase causes apoptosis of neutrophils and accumulation of monocytes in the area of inflammation which is a sign of chronic inflammation. ${ }^{27}$

In this study, a significant decrease of IL-6 levels in the serum and adenoid surfaces $(p<0.05)$ before and after treatment of mometasone furoate was observed. The results of this study were in line with the findings of Suheryanto et al. ${ }^{28}$ that in 16 patients with adenoid hypertrophy, there was a significant decrease in serum IL-6 levels after using mometasone furoate nasal spray for 6 weeks. Decreased serum IL-6 was correlated with reduced adenoid size through lateral skull radiological features.

Wang et al. ${ }^{5}$ on their study reported the presence of IL- 6 expression in the examination of nasopharyngeal secretions from the adenoid mucosal surface of patients with adenoid hypertrophy planned for adenoidectomy. The severe group (choanal obstruction more than $80 \%$ ) had higher adenoid surface IL-6 levels than the moderate group (choanal obstruction less than $80 \%$ ). The concentration of IL- 6 in nasopharyngeal secretions is positively correlated with the vascular endothelial growth factor (VEGF) production in adenoid tissue. IL-6 can induce VEGF production, which regulates vascular endothelial cell migration and blood vessel formation in vitro.

The decrease of IL-6 level that are significant both locally on the surface of adenoids and serum are associated with antiinflammatory effects of mometasone furoate. The mechanism of action of corticosteroids takes place through GRs. GR $\alpha$ and GR $\beta$ expression is found in adenoid lymphoid tissue and tonsils of children with OSA as well as in recurrent throat infections. Like other tissues, GR $\alpha$ expression is higher than GR $\beta$ in lymphoid tissue. In adenoid or tonsil tissues, GR $\alpha$ and GR $\beta$ immunoreactivity are found to be more prominent in the epithelial layer and extrafollicular area. ${ }^{18}$

In our study a significant positive correlation was found between the decrease in adenoid size and the decrease in the serum and adenoid surface IL-6 levels. This showed that the greater the decrease in adenoid surface IL-6 level was accompanied by the decrease in serum IL- 6 and the decrease in adenoid size as measured by the ratio of adenoid compared to choanal diameter through nasoendoscopy.

The mechanism of action of intranasal corticosteroids is mediated through decreased production of IL- 6 by adenoid lymphocytes which, in turn, leads to decreased growth and differentiation of these adenoid cells and decreased adenoid size. A decrease in IL-6 levels on the surface of the adenoids can cause a parallel decrease in serum levels and a reduction in the proinflammatory effect of cytokines observed in children with OSA. ${ }^{29}$

Interleukin-6 is reported to inhibit T cells from apoptosis, which triggers infiltration of chronic inflammatory cells. Trans-signaling IL-6 also triggers the release of IL-6 from fibroblasts and endothelial cells in a positive autocrine feedback system. With the decrease in the IL-6 levels, the apoptosis of cells in adenoid tissue increases. The effect of IL-6 in inducing VEGF in adenoid lymphoid tissue has been reported. A decrease in IL- 6 can be followed by a decrease in VEGF production whose role in angiogenesis stimulates tissue hyperplasia. ${ }^{5}$

From this study we concluded that the use of intranasal mometasone furoate could decrease the IL-6 levels of adenoid surface and serum, and the size of adenoid in patients with adenoid hypertrophy. 


\section{REFERENCE}

1. Major M, El-Hakim H, Witmans M, Major PW, Flores-Mir C. Adenoids hypertrophy in pediatric sleep disordered breathing and craniofacial growth: the emerging role of dentistry. J Dent Sleep Med. 2014; 1(2): 83-7.

2. Chang SJ, Chae KY. Obstructive sleep apnea syndrome in children: Epidemiology, pathophysiology, diagnosis and sequelae. Korean J Pediatr. 2010; 53(10): 863-71.

3. Hunter CA, Jones SA. IL-6 as a keystone cytokine in health and disease. Nat Immunol. 2015; 16(5): 448-57.

4. Ivarsson M, Lundin BS. Cytokines produced by $\mathrm{T}$ cells in adenoid surface secretions are mainly downregulatory or of Th1 type. Acta Otolaryngol. 2006; 126 (2): 186-90.

5. Wang H, Bai J, Zhang J, Yang W, Zuo K, Li H. IL-6 promotes the expression of vascular endothelial growth factors through the p38 signaling pathway in hypertrophied adenoids in children. Int J Pediatr Otorhinolaryngol. 2013; 77 (2): 205-9.

6. De La Torre Gonzalez C, Mayorga-Butrón J, A Macías Fernández L, M Sih T, ChaverriPolini J, M Melendez-Medina A, et al. Pan American Guideline on Tonsillitis and Adenoids Hypertrophy. American Academy of Otolaryngology-Head and Neck Surgery Foundation. (AAOHNSF) 2012; 147: 234.

7. Jung YG, Kim HY, Min JY, Dhong HJ, Chung SK. Role of intranasal topical steroids in pediatric sleep disordered breathing and the influence of allergy, sinusitis, and obesity on treatment outcome. Clin Exp Otorhinolaryngol. 2011; 4 (1): 27-32.

8. Berlucchi M, Barbieri D, Nassif N. Intranasal steroid treatment for adenoids. In: Adkins C, editor. Corticosteroids and Steroid Therapy New Research, Edition 2: Nova Science Publishers; 2015. p. 41-61.

9. Chohan A, Lal A, Chohan K, Chakravarti A, Gomber S. Systematic review and meta-analysis of randomized controlled trials on the role of mometasone in adenoid hypertrophy in children. Int J Pediatr Otorhinolaryngol. 2015; 79 (10): 1599-608.

10. Lapinska I, Zawadzka-Glos L. Adenoid And Tonsils Hypertrophy-Symptoms And Treatment. New Med. 2016; 20 (4): 103-6.
11. Kang KT, Chou CH, Weng WC, Lee PL, Hsu WC. Associations between adenotonsillar hypertrophy, age, and obesity in children with obstructive sleep apnea. PloS one. 2013; 8(10): 1-8.

12. Alharbi F, Ahmed MR. Mometasone furoate aqueous nasal spray in management of adenoidal hypertrophy in children. Pan Arab J Rhinol. 2018; 8(2): 88-94.

13. Solmaz F, Aşçıoğlu M, Durgut O, Dikici O, Haksever M, Akduman D. Are nasal steroids effective in children with adenoid hypertrophy?. The European Research Journal. 2019; 5(2): 311-8.

14. Yilmaz HB, Celebi S, Sahin-Yilmaz A, Oysu C. The role of mometasone furoate nasal spray in the treatment of adenoidal hypertrophy in the adolescents: a prospective, randomized, cross-over study. Eur Arch Otorhinolaryngol. 2013; 270(10): 2657-61.

15. Ozbilgin MK, Polat S, Mete UO, Tap $\mathrm{O}$, Kaya M. Antigen-presenting cells in the hypertrophic pharyngeal tonsils: a histochemical, immunocystochemical and ultrastructural study. J Invest Allergol Clin Immunol. 2004; 14(4): 320-8.

16. Külekçi M, Mama Torun M, Duru Ipek H, Ozdemir S, Can G, Develioglu O, et al. Bacteriology of Adenoids in Children with Adenoid Hypertrophy despite Mometasone Furoate Administration. Pediatr Infect Dis J. 2016; 1(4): 30.

17. Kadmiel M, Cidlowski JA. Glucocorticoid receptor signaling in health and disease. Trends Pharmacol Sci. 2013; 34 (9): 518-30.

18. Goldbart AD, Veling MC, Goldman JL, Li RC, Brittian KR, Gozal D. Glucocorticoid receptor subunit expression in adenotonsillar tissue of children with obstructive sleep apnea. Pediatr Res. 2005; 57 (2): 232.

19. Önal M, Yılmaz T, Bilgiç E, Müftüoğlu S, Sözen T, Bajin MD. Possible role of apoptosis in the pathogenesis of adenoid hypertrophy and chronic adenoiditis: Prospective casecontrol study. Auris Nasus Larynx. 2015; 42 (6): 449-52.

20. Kheirandish-Gozal L, Serpero L, Dayyat E, Kim J, Goldman J, Snow A, et al. Corticosteroids suppress in vitro tonsillar proliferation in children with obstructive sleep apnea. Eur Resp J. 2009; 33: 1077-84. 
21. Inoshita A, Kasai T, Matsuoka R, Sata N, Shiroshita N, Kawana F, et al. Age-stratified sex differences in polysomnographic findings and pharyngeal morphology among children with obstructive sleep apnea. J Thorac Dis. 2018; 10 (12): 6702-10.

22. Wang J, Zhao Y, Yang W, Shen T, Xue P, Yan $\mathrm{X}$, et al. Correlations between obstructive sleep apnea and adenotonsillar hypertrophy in children of different weight status. Sci Rep. 2019; 9 (1): 11455.

23. Grzanka A, Misiołek M, Golusiński W, Jarząb J. Molecular mechanisms of glucocorticoids action: implications for treatment of rhinosinusitis and nasal polyposis. Eur Arch Otorhinolaryngol. 2011; 268 (2): 247-53.

24. DelRosso LM. Epidemiology and diagnosis of pediatric obstructive sleep apnea. Curr Probl Pediatr Adolesc Health Care. 2016; 46 (1): 2-6.

25. Bianchi E, Magliulo G, Marcotullio D, Taurone $\mathrm{S}$, Ierinò $\mathrm{R}$, Pompili $\mathrm{E}$, et al. Inflammatory Profile of Neurotrophins, IL-6, IL1- $\beta$, TNF- $\alpha$, VEGF, ICAM- 1 and TGF- $\beta$ in the Human Waldeyer's Ring. Eur J Inflamm. 2013; 11 (3): 763-75.

26. Mutlu M, Vuralkan E, Yardim Akaydin S, Akin I, Miser E. Effects of adenoids / tonsillectomy on inflammatory response in snoring children with witnessed apnea. Clin Otolaryngol. 2014; 39 (5): 266-71.

27. Gabay C. Interleukin-6 and chronic inflammation. Arthritis Res Ther. 2006; 8 (2): S3.

28. Suheryanto R, Harahap SP, Maharani I. Pengaruh mometasone furoate terhadap kadar Interleukin-6 serum pada penderita hipertrofi adenoid. ORLI. 2019; 49 (2): 144-51.

29. Esteitie R, Emani J, Sharma S, Suskind DL, Baroody FM. Effect of fluticasone furoate on interleukin-6 secretion from adenoid tissues in children with obstructive sleep apnea. Arch Otolaryngol Head Neck Surg. 2011; 137 (6): 576-82. 